Int. J. Electrochem. Sci., 11 (2016) 9326 - 9339

\title{
In Vitro Bioactivity, Degradation Property and Cell Viability of the CaP/Chitosan/Graphene Coating on Magnesium Alloy in m- SBF
}

\author{
Jie Zhang ${ }^{1,2^{*}}$, Fangfang $\mathrm{Zhu}^{1}$, Yu Zhang ${ }^{1}$, Ming $\mathrm{Hu}^{1}$, Yanxia Chi ${ }^{1}$,Xiangyu Zhang ${ }^{1}$, Xiaoling Guo ${ }^{1}$ \\ ${ }^{1}$ Pharmaceutical Research Institute in Heilongjiang Province, Jiamusi university, Jiamusi 154007, \\ China \\ ${ }^{2}$ Department of neuro intern, First Affiliated Hospital of Harbin Medical University, Harbin 150001, \\ China \\ *E-mail: zjie612@163.com
}

doi: $10.20964 / 2016.11 .63$

Received: 8 August 2016 / Accepted: 15 September 2016 / Published: 10 October 2016

$\mathrm{CaP} /$ chitosan/graphene coating on $\mathrm{Mg}$ alloy was obtained by electrophoretic deposition (EPD) and transformation in a phosphate buffer solution (PBS). The microstructures and compositions of the composite coatings were studied by scanning electron microscope (SEM), Fourier-transformed infrared spectroscopy (FTIR), X-ray diffraction (XRD) and Raman spectroscopy. The element concentration was investigated by inductively coupled plasma optical emission spectrometer (ICPOES) test. The degradation behavior of $\mathrm{Mg}$ based $\mathrm{CaP} /$ chitosan/graphene in $\mathrm{m}-\mathrm{SBF}$ was researched by soaking experiment and electrochemical performance test. The cytotoxicity of the prepared material to SaOS-2 cells was determined by CCK assay. The results indicated that addition of graphene had a positive effect on improving the bioactivity and cell viability of the CaP/chitosan coating. $\mathrm{CaP} /$ chitosan/graphene coating could protect the $\mathrm{Mg}$ alloy from corroding in $\mathrm{m}-\mathrm{SBF}$.

Keywords: Graphene, Mg alloy, Bioactivity, Hydroxyapatite, Bone-like apatite

\section{$\underline{\text { FULL TEXT }}$}

(C) 2016 The Authors. Published by ESG (www.electrochemsci.org). This article is an open access article distributed under the terms and conditions of the Creative Commons Attribution license (http://creativecommons.org/licenses/by/4.0/). 